\title{
ECHINUS ESCULENTUS.
}

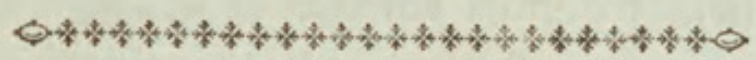

\section{CHARACTER GENERICUS.}

Corpus fubrotundum, crufta offea tectum, fpinis mobilibus fxpius aculeatum.

Os quinquevalve fubtus.

$$
\text { Lin. Syft. Nat. p. } 1102 .
$$

CHARACTER SPECIFICUS, छैC.

ECHINUS fubglobofus, fpinis brevibus violaceis.

ECHINUS hemifphærico-globofus ambulacris denis, areis obfolete verrucofis.

$$
\text { Lin. Syft. Nat. p. } 1102 .
$$

ECHINUS fubglobofus, vertice plano.

$$
\text { Lin. Faun. Suec. 1. } 1289 .
$$

ECHINOMETRA.

Aldr.aq. p. $405 \cdot 409$.

Diverfa admodum fpecierum eft tum forma tum magnitudo quas complectitur echinorum marinorum numerofiffimum genus. Reperiuntur aliquæ in litoribus noftratibus; plures autem exoticæ funt. Illam repræfentavimus quæ fpecierum Britannicarum vulgatior eft. Conftat animal ipfum e molli fubftantia, 
fubftantia, corpore in fegmenta, eodem fere modo quo malum aurantiam, divifo. Os, fuperius fitum, quinque continet dentes validos et acuminatos. Stomachi aliorumque vifcerum fere circulatim difpofitorum multa eft longitudo. Fulcitur totum corpus offum erectorum columnis in medio pofitis. Teftam exteriorem contegunt innumeræ fpinæ, mobiles, et acutæ, quæ fingulæ miro modo cum tuberculis fuperficiariis articulatim connexæ funt, et epidermidi teftam veftienti fortiter alligatæ. Harum ope ad libitum progreditur animal; tantaque illis infita eft vitalitas, ut echino ipfo divulfo feu diffecto, partes ipfius teftæ non raro huc illuc diffractæ obambulent. Inter fpinas, quarum feries in longitudinem ducta varias teftr divifiones occupat, innumera funt foramina, totidem tentaculis fupra fitis refpondentia, quorum ope affigit fe animal rupibus, aliifque id generis, eodem fere modo quo hirudo cauda; poffunt enim tentaculorum extremitates ad libitum vel contrahi vel dilatari.

Color fpeciei, quam depinximus, cum fpinis obtegitur, plerumque eft violaceo-lividus; interdum tamen dominatur magis color fubvirefcens. Tefta ipfa fpinis et epidermide denudata, pallido-rufefcit; tuberculis quibus accreverunt fpinæ fuperficiem quafi margaritiferam reddentibus. Speciem de qua loquimur in cibis lautioribus habuerunt Romani; illamque præcipue commemorat garrulus quidam Epicuri de grege porcus, quem lepide irridet Horatius. 
Notandum eft, licet inter echinum marinum, et echinum vulgarem terreftrem, feu Erinaceum Euro. peum Linnæi, nulla fit vera et genuina affinitas, fimilem tamen effe fpinarum tum internam tum externam conformationem, nifi quod erinacei velut cornex, marini quafi calcariæ feu lapidex fint fpinæ. 



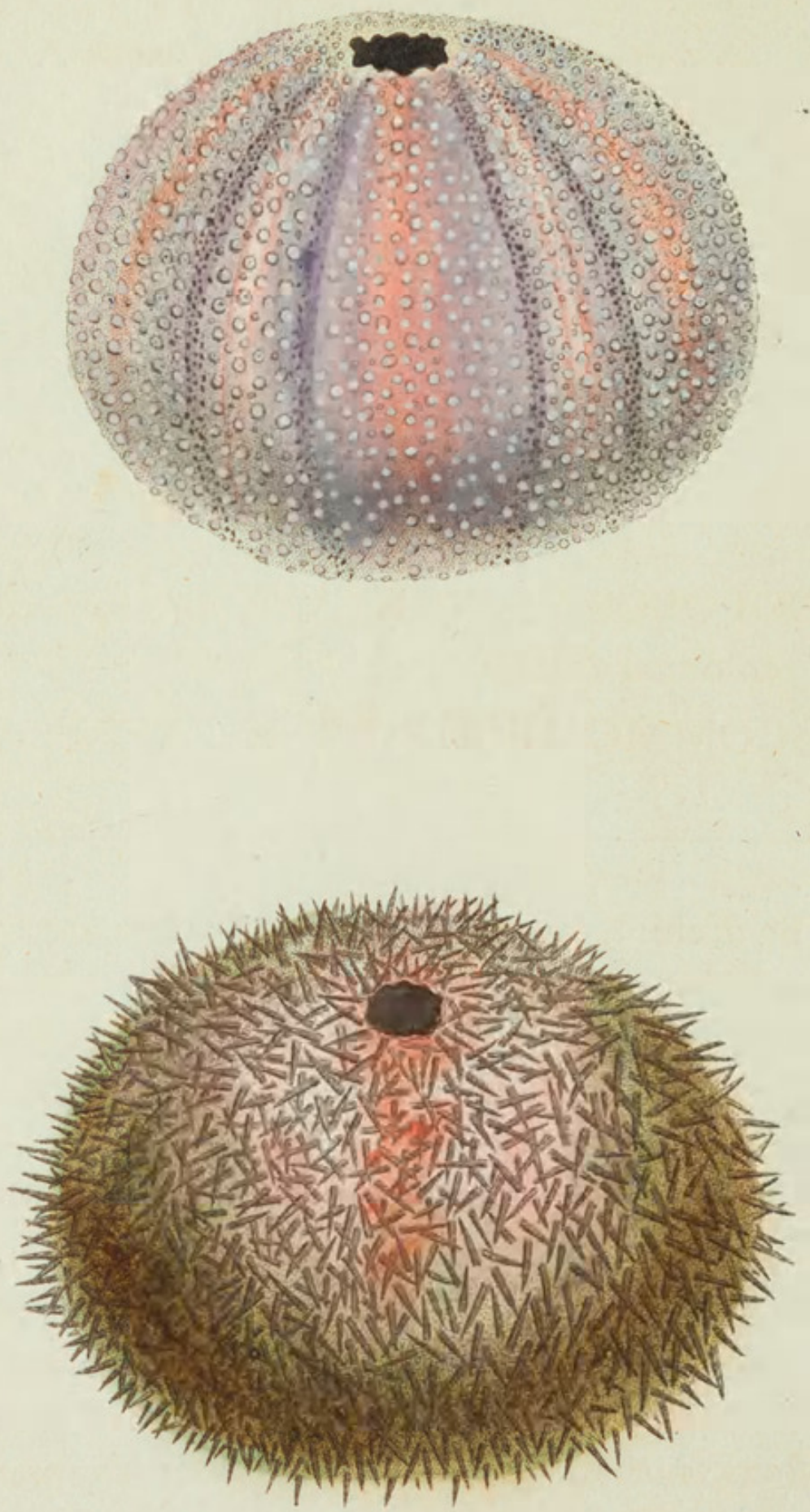
THE

\section{ESCULENT ECHINUS。}

$0 * * * * * * * * * * * * * * * * * * * * * * 0$

\section{GENERIC CHARACTER.}

Body covered with a futured cruft, generally furnifhed with moveable fpines.

Moutb quinquevalve, placed beneath.

SPECIFIC CHARACTER, $\Xi^{\circ}$.

SUBGLOBOSE ECHINUS, with thort violetcoloured fpines. The COMMON ECHINUS, or SEA-URCHIN.

The Echini, or Sea-Urchins, as they are fometimes called, form an extremely numerous genus, of which the fpecies differ greatly from each other in point of fhape and general appearance. Several are natives of our own country, but by far the major part are exotic animals. Of the Britifh fpecies the moft common is that reprefented on the plate, which is very frequently found on many of our coafts. The animal is of a foft fabric, and the body is marked as it were into a certain number of parts or divifions, not ill refembling thofe of an orange: the mouth is fituated at the lower or under part, and 
and is armed with five ftrong teeth, of a fharpened form : the ftomach and inteftines, which are of confiderable length, are difpofed in a fomewhat circular direction, and the whole body is fupported internally by a fet of upright bones or columns. On the outfide of the fhell are feated a prodigious number of tharp, moveable fpines, curioufly articulated with the tubercles on the furface, and connected by ftrong ligaments to the fkin or epidermis with which the fhell is covered. Thefe are the inftruments of motion, by the affiftance of which the animal conveys itfelf at pleafure to any particular fpot; and fo tenacious are they of the vital principle, that on opening the animal, it is no very uncommon circumftance to obferve the feveral parts of the broken fhell walk off in different directions. Between the fpines, difpofed in a continued longitudinal feries on the feveral divifions or regions of the fhell, are an infinite number of very fmall foramina, communicating with an equal number of tentacula, placed above them. There are the inftruments by which the creature affixes itfelf to any object, and ftops its motion. They are poffeffed of a very high degree of contractile power, and are furnifhed at the extremities with an expanfile part, which may be fuppofed to operate as a fphincter, or as the tail of a leech, and to faften the animal fecurely to rocks, or other fubftances to which it choofes to adhere.

The general color of the common echinus, when covered with its fpines, is a dull violet; though fome- 
fometimes a greenifh tinge predominates. The fhell itfelf, when deprived of its fpines, is of a pale reddifh tinge, the tubercles on which the fpines were mounted appearing like fo many pearly protuberances on the furface. The fpecies here reprefented is efculent, and is confidered as no unpleafant article of food. It was alfo a difh well known amongft the ancient Romans, and is commemorated, amongft other delicacies, by the loquacious epicure defcribed by Horace.

It is remarkable, that though there is not the leaft real affinity between the two animals, yet the fpines of the Echinus are of the fame general ftructure, both internally and externally, with thofe of the Hedge-Hog; except that thofe of the Echinus are of a calcareous or ftrong nature, while thofe of the Hedge-Hog are of a horny fubftance. 


\section{$2 \mathrm{BHL}$ Biodiversity Heritage Library}

Shaw, George. 1795. "The Esculent Echinus, Echinus esculentus [PI. 223]." The Naturalist's Miscellany 7(LXXIV), https://doi.org/10.5962/p.310766.

View This Item Online: https://www.biodiversitylibrary.org/item/276356

DOI: https://doi.org/10.5962/p.310766

Permalink: https://www.biodiversitylibrary.org/partpdf/310766

\section{Holding Institution}

Museums Victoria

\section{Sponsored by}

Atlas of Living Australia

\section{Copyright \& Reuse}

Copyright Status: Public domain. The BHL considers that this work is no longer under copyright protection.

This document was created from content at the Biodiversity Heritage Library, the world's largest open access digital library for biodiversity literature and archives. Visit BHL at https://www.biodiversitylibrary.org. 